\title{
The History of Discovery and Research of the Archeological Micro-Region of Tytkesken (the Left Bank of the Lower Part of the Katun River)
}

\author{
Artur L. Kungurov and Kseniia V. Pobeguts* \\ Altai State University \\ 61 Lenin Str., Barnaul, 656049, Russia
}

Received 14.11.2014, received in revised form 30.11.2014, accepted 26.12.2014

This article is about the first archeological monument - the group of archaeological sites named Tytkesken 6, which was first mentioned in 1983. M.T. Abdulganeev was looking for the monuments, which could be damaged while building the Katun Water Power Station and marked them on a special map. In 1984 the scientists of Barnaul State University found another group of mounds situated not far from the first one. They were named Tytkesken 1 and Tytkesken 2.They continued their work and found many sufficient artifacts which were left by the ancient people on the places of their settlements. They were named Tytkesken 3 and Tytkesken 4 and 5. The scientists were researching them since 1984 till 1991 and found that there were many objects made from stone, bronze and iron, which illustrated that people lived there from 5 century B.C. till 1 century A.D. All those settlements were found on the right bank of the river. In 1988 the scientists came to the conclusion that the grave complexes situated on the right bank of the river and on the left one were different from each other. That's why the one on the left bank was named Tytkesken 6. From 1988 till 1993 more than 60 monuments of skiffs period were researched (5-3 centuries B.C.) the scientists also learned about some settlements of Turkic period (552 year A.D.). A great number of specialists took part in the work. They were pupils, students, scientists from many towns and cities of Siberia. From 1983 till 2006 more than 20 archeological monuments were found and researched. But our scientists are sure that much more artifacts could be found in the valley of the river Tytkesken in the nearest future.

Keywords: archaeological sites, discovery, research, Tytkesken, archaeological microregion, scientists.

Research area: history.

The first archaeological monument - the Barrow Group Tytkesken 6 was first recorded in 1983 in the course of works by M.T. Abdulganeev, who was searching and mapping archeological sites within the area of destruction and flowage formed by the construction of the Hydroelectric Power Station on the Katun River. Initially,
M.T. Abdulganeev gave the same name "Tytkesken 1" and "Tytkeskenem 2" to the graves on the right and the left banks of the river; it was a multi-layered settlement, which when discovered was believed to be a site of the Mesolithic period (Abdulganeev, 1983, p.189; Abdulganeev, Kiriushin, Neverov, 1992 , pp. 26-29, 100-102).

(C) Siberian Federal University. All rights reserved

* Corresponding author E-mail address: instruktor7@mail.ru, rector@asu.ru 
In 1984 scheduled regular surveys of the monuments in the estuary zone of the Tytkesken River began; these were primarily excavations of the multilayer monument Tytkesken 2. In 1984-1986, the excavations of the settlement were conducted by A.L. Kungurov (Kungurov, Kungurova, 1986, p.184). In the course of these works in the talus of the left bank, which at that time was rather destroyed, A.L. Kungurov recorded individual finds of stone tools and ceramics. In the period 1984-1987's A.L. Kungurov and N.Y. Kungurova discovered new monuments that were given the names of Tytkesken 3, 4, and 5 (Kiriushin, Kungurov, 1991, p.67-69). The multilayer settlement of Tytkesken 3, located on the right side of the Tytkesken river valley 300 m upstream from Tytkesken 2, was investigated during 1988-1991. It was the base object for the outlining and characterization of the late stage of the Ust-Seminsky Mesolithic culture and characteristics of the various parts of the Stone, Bronze and Iron Ages (Kungurov, 1994, pp. 43 - 58; Semibratov, 1991, p. 65 - 66; 1994, pp. 97-111).

In 1988 after the excavations of the barrow group on the right bank, it became clear that the right bank and left bank funerary complexes are different. Therefore, the last one was named Tytkesken 6 (VI) (Kiriushin, Tishkin, Mamadakov, 1992, p.125).

In the period from 1988 to 1993 several expeditions of Altai State University under the supervision of Y.F. Kiryushin studied more than 60 mounds of Scythian time (Pazyryk Culture of V-III centuries B.C.). The basis of the necropolis was a chain of early Iron Age burial mounds, elongated from north to south along the edge of the terrace of the left bank of the Katun. A separate planigraphic group was formed by burial structures of the early Scythian period, located in the southern part of the valley of the Katun near the rocky outcrops to the north of the field road going the upstream of the Tytkesken. The diameter of the stone mounds ranged from 3.2 to $9.5 \mathrm{~m}$, depth of the wells - from 1.3 to $3 \mathrm{~m}$. All the graves traced the remains of wooden funerary structures. The dead lay on their right side, with knees bent legs, head east or east - southeast. The inventory included ceramic vessels, stone "censer", bronze daggers, knives, and a mirror. Of greatest interest were a bronze dagger from the mound number 4 and a bronze mirror from the barrow № 2. The dagger was artistically designed in the form of two heads of vultures, and handle of the mirror was made in shape of a lying camel. This necropolis for the Mountainous Altai remains to be the largest in the number of studied mounds ordinary people of the Scythian epoch, some of the materials were published in monographs (Kiriushin, Stepanov, Tishkin 1995, p. 6-19).

When studying the southern group of the funerary objects in the archaeological complex some new settler finds were discovered, which had appeared there during the construction of gravestone designs. The found artifacts (pottery, stone tools) had an earlier age than the burial mounds. In 1990 in order to identify the cultural layer in the southern part of the site, adjacent to the valley of the Tytkesken river was made a reconnaissance excavation, which demonstrated the existence of cultural layers of the Bronze Age, Chalcolithic (Bolshemys Culture) and Neolithic (Kiriushin, Kungurov, 1994, pp. 111123; Kiriushin, Kungurov 1991, pp. 67-69).

In addition to these findings in the study of burial mounds in 1989 under the floors of the Pazyryk grave structures a partially destroyed stone layout and a burial of a teenager in the pit were found. The position of the deceased (stretched on the back with the knees raised), other findings (bone tubes for decorating clothes, polished stone adze) as well as the skeleton painted with ocher previously allowed the scholars to attribute the 
burial to the Chalcolithic era. In the publication of 1995 this facility received the number 61 and was referred to the complex of Bolshemys Culture (Kiriushin, Kungurov, Stepanova, 1995, pp. 108114). However, further anthropological studies were confident enough to date the grave to the Athanasian time.

In 1989 when studying the area of the graves complex through the continuous excavation, there seven mounds were studied, they were attributed to the Bulan-Koba culture period of Late Antiquity (II - IV century AD). The facilities were extended in a chain oriented south-north, the dead were buried stretched on the back in the stone boxes and oriented head to the west. The following items were found there: bone and iron arrowheads, horn pads for the bow, bone tubes, iron elements for belts, buckles, knives, beads and ceramic spindle whorls (Kiriushin, Tishkin, Mamadakov, 1992, pp. 125-130, 222-226).

Turkic burial complex (the three mounds (№ 1, 5, 10), located east of the burial structures contain fairly rich burials of soldiers with horses or horse equipment (Mound 1). Found bits, stirrups made of iron, and iron horn psalm items, weapons and equipment, parts and accessories of waistband, horn pads for the bow. The dating is defined by researchers as follows: mound 5 the beginning of the formation I Turkic khanate (around $552 \mathrm{AD}$ ); mound 10 - stay in the Altai Chabysh-Kagan (630-650 AD.) mound 1 - the beginning of the emergence the Second Eastern Turkic Khaganate (about 682 AD).

The works on the settlement and burial complexes in the valley and estuary zone of the Tytkesken river involved a sufficiently large number of professionals, graduate students, students and lovers of history and archeology of many cities in Siberia. We should note the archaeologists Y.F. Kiryushin, K.Y. Kiryushin, A.L. Kungurov, N.Y. Kungurova, A.A. Tishkin, Y.T. Mamadakov, N.F. Stepanova, S.V. Neverov, V.P. Semibratov, V.V. Gorbunov, M.T. Abdulganeev; the anthropologist A.R. Kim; the geologists G.Y. Baryshnikov, A.M. Maloletko; the historians V.V. Vladimirov, S.V. Tsyba, O.F. Kungurov; the artist M.G. Mingulov. The excavations were visited by A.P. Derevyanko, V.T. Petrin, S.V. Nikolaev, A.B. Dolinsky (USA) and many others.

During the period of $1983-2006$ 's, more than 20 archeological sites were discovered, while researchers repeatedly pointed out the fact of the need for careful study of the area. A special investigation of the Tytkesken Valley has never been conducted - all the objects were discovered during steady-state operation, almost by accident: during educational excursions, during chores, exploring caves, etc. Most likely, the archaeological sites of different periods in the future will be discovered many times more.

\section{References}

1. Abdulganeev M.T. Works in mountainous and forest-steppe Altai [Raboty $v$ Gornom $i$ lesostepnom Altaye]. Moscow, 1985. p. 189.

2. Abdulganeev M.T., Kiriushin Y.F., S.V. Neverov Emergency excavations in the middle of the Katun. Problems of preservation, and study of archaeological monuments [Avariynyye raskopki na sredney Katuni. Problemy sokhraneniya, ispol'zovaniya i izucheniya pamyatnikov arkheologii]. Gorno-Altaisk, 1992. Vol. 3, pp. 26-29, 100-102.

3. Kiriushin Y.F., Kungurov A.L. Finds of Early Bronze Age in the Middle Katun. Conservation and Research of archaeological sites of the Altai [Nakhodki ranney bronzy na Sredney Katuni. Okhrana i issledovaniya arkheologicheskikh pamyatnikov Altaya]. Vol. 2. Barnaul, 1991, pp. 67-69. 
4. Kiriushin Y.F., Tishkin A.A., Stepanov N.F., Kungurova N.Y. The Settlement of Sary-Bel [Poseleniye Sary-Bel]. Proceedings of archeology laboratory [Izvestiya laboratorii arkheologii]. № 1. Gorno-Altaisk, 1995, pp. 6 - 19.

5. Kiriushin Y.F., Kungurov A.L. The Multilayer Settlement of Tytkesken 6 upon the Katun River. Archaeology of the Altai Mountains [Mnogosloynoye poseleniye Tytkesken' 6 na Katuni. Arkheologiya Gornogo Altaya]. Barnaul, 1994. pp. 111-123.

6. Kiriushin Y.F., Kungurov A.L. Stepanov N.F. The Burial of the Cave 1 in the Lower Tytkesken. Paleoecology and ancient human settlement in North America and Asia [Pogrebeniye iz peshchery I Nizhney Tytkesken'. Paleoekologiya i rasseleniye drevnego cheloveka v Severnoy Azii i Amerike.]. Proc. rep. Krasnoyarsk, 1992, pp 282-286.

7. Kiriushin Y.F., Kungurov A.L. Stepanov N.F. Archaeology STP-I [Arkheologiya NTP-I]. Barnaul, 1995. $150 \mathrm{p}$.

8. Kiriushin Y.F., Tishkin A.A., Mamadakov Y.T. Some of the results of archaeological research of the monument Tytkesken-VI in Central Katun. Questions archeology of the Altai and Western Siberia metal era [Nekotoryye rezul'taty arkheologicheskikh issledovaniy pamyatnika Tytkesken'-VI na Sredney Katuni. Voprosy arkheologii Altaya i Zapadnoy Sibiri epokhi metalla]. Barnaul: Publishing House of the Barnaul State Pedagogical University, 1992, pp. 125-130, 222-226.

9. Kungurov A.L. The upper layers of cultural settlements Tytkesken. Archaeology of the Altai Mountains [Verkhniye kul'turnyye sloi poseleniya Tytkesken'. Arkheologiya Gornogo Altaya]. Barnaul, 1994. P. 43-58.

10. Kungurov A.L., Kungurova N.Y. Work in the foothills of the Altai [Raboty v predgor'yakh Altaya]. AB 1984: Science, M., 1986, p. 184.

11. Kungurova N.Y. Microlithic monuments of the Central Katun. Northern Asia in the era of stone [Mikroliticheskiye pamyatniki Sredney Katuni. Severnaya Aziya v epokhu kamnya]. Novosibirsk, 1987, pp. 31-57.

12. Semibratov V.P. Mesolithic Settlement Complex Tytkesken 3. Problems of Archeology and Ethnography of Siberia and the Far East [Mezoliticheskiy kompleks poseleniya Tytkesken' 3. Problemy arkheologii i etnografii Sibiri i Dal'nego Vostoka]. Vol. 1. Krasnoyarsk: KGPI, 1991. p. 65-66.

13. Semibratov V.P. Final Mesolithic complex of the settlement Tytkesken 3. Archaeology of the Altai Mountains [Final'nomezoliticheskiy kompleks poseleniya Tytkesken' 3. Arkheologiya Gornogo Altaya]. Barnaul, 1994, p. $97-111$.

\section{Список сокращений}

АГУ - Алтайский государственный университет

$\mathrm{AO}$ - археологические открытия

БГПУ - Барнаульский государственный педагогический университет

ГЭС - Гидроэлектростанция

США - Соединенные Штаты Америки 


\title{
История открытия и исследования \\ археологического микрорайона Тыткескень \\ (левобережье нижнего течения р. Катунь)
}

\author{
А.Л. Кунгуров, К.В. Побегуц \\ Алтайский государственный университет \\ Россия, 656049, Барнаул, пр. Ленина, 61
}

\begin{abstract}
Археологический комплекс разновременных памятников Тыткескень имеет длительную и насыщенную историю изучения. Первые находки упоминаются в 1983 г. М.Т. Абдулганеевым. Он производил изыскания памятников, которые могли бы быть уничтожены при строительстве Катунской ГЭС и произвел их картографирование. В 1984 г. ученые Барнаульского государственного университета обнаружили другую группу памятников, расположенную недалеко от первой, - Тыткескень I и Тыткескень II, позже были найдены Тыткескень III и Тыткескень IV и V. Их исследования проходилих с 1984 по 1991 г. Были найдены предметы из камня, бронзы и железа (V до н.э.). Все памятники расположены на правом берегу реки Тыткескень. В 1988 г. учеными на правом берегу реки Тыткескень был открыт памятник Тыткескень VI. C 1988 по 1993 г. были исследованы более 60 памятников скифского (V-III до н.э.) и тюркского периодов (года 552 до н.э.). Большое количество специиалистов приняли участие в работе. Все они были учениками, студентами, учеными из различных городов Сибири. С 1983 по 2006 г. были найдены и исследованы более 20 археологических памятников.
\end{abstract}

Ключевые слова: археологические памятники, открытие, исследования, Тыткескень, археологический микрорайон, ученые.

Научная специальность: 07.00.00 - исторические науки. 